Journal of Qualitative Criminal Justice \& Criminology

\title{
Welcome to the Second Issue of the Journal of Qualitative Criminal Justice \& Criminology (JQCJC)!
}

Willard M. Oliver ${ }^{1}$

${ }^{1}$ Sam Houston State University

Published on: Oct 01, 2013

DOI: $10.21428 / 88 d e 04 a 1.8 b 79 c 42 f$

License: Creative Commons Attribution 4.0 International License (CC-BY 4.0). 
In light of this being the second issue of the new journal and the last issue of Volume 1, I have many people to thank for making this issue - this volume - this journal - a reality.

The first group of people I would like to thank for their dedicated work on making this journal come to fruition are the many people who have agreed to conduct peer-reviews for JQCJC. All of the reviewers for Volume 1 are listed on the first pages of this issue. These are the people who have graciously answered my pleas for help and have given their precious time to ensure the high quality of this journal. To them, on behalf of everyone involved, and from my own deepest gratitude, I extend a JQCJC thank you!

I would also like to single out one individual who agreed to conduct a review and then, after finishing the review, agreed to my further entreaties to join the JQCJC Editorial Board, and that is Dr. Jody Miller from the School of Criminal Justice at Rutgers University. Welcome aboard, Jody!

As this is the first issue since the premier of the journal, I also wanted to acknowledge my appreciation for the dozens of congratulatory e-mails for the inaugural issue of the journal, which was published on April 15, 2013. Many of you noted that "the website looks great" and told me "nice job with the journal." Some of my favorite comments included, "What a fantastic looking inaugural issue!" and "I have already spotted one article that I will be using/citing in some of my other work." I should also note that many of you voiced support through our Facebook page as well as via Twitter. Regarding the latter, one editorial board member noted that his tweet about the inaugural issue helped him to achieve an alltime personal record for retweets - I was glad the journal could help! I really must say that I have appreciated all of the positive reactions to the first issue and I would like to thank everyone for taking the time to reaffirm the reason why I committed myself two years ago to making this journal become a reality.

While I was really excited about publishing the inaugural issue, I am equally excited about the current issue at hand. In my opinion, I believe the quality of the articles contained herein demonstrates that the journal will have staying power. Whether it is articles from well-established qualitative scholars such as Ron Weitzer, Rod Brunson, Richard Tewksbury, or Scott Decker, to the qualitative research of such rising stars as Brittnie L. Aiello (Merrimack College) or Andrea Cantora (University of Baltimore), I hope you will agree with me that the journal is achieving its aim of publishing only high quality qualitative research.

I must also extend my thanks to the many people behind the journal who have made this issue and the journal happen. I would first like to extend an acknowledgment and thanks for the support I have received from the executive board and membership of the Southwestern Association of Criminal Justice, as well as the journal's host institution, Sam Houston State University. Second, the copy- 
editing by Ronda Harris from Sam Houston's Writing Center has been invaluable to keeping the quality of the journal high and every one of the authors in this volume knows exactly what I am talking about. Third, to my book review editor Kevin Steinmetz, who brought in seven book reviews for this issue, I must extend my sincere thanks. As someone who has a strong passion for qualitative research methods and is a rising qualitative star in his own right, it is one aspect of this journal I have not had to worry about. Finally, I would like to extend my appreciation to the production team of Harriet McHale and Melina Gilbert, for simply put: the journal would not look like a journal if it was not for their hard work and dedication.

As the first volume of the Journal of Qualitative Criminal Justice \& Criminology comes to a close, I hope you find both this issue and the entire volume to be a significant contribution to CJC, and that you will consider JQCJC as an outlet for your future qualitative research. 